\title{
SYNTHESIS AND ANTIMICROBIAL ACTIVITY OF CONDENSED AND UNCONDENSED QUINOXALINES
}

\author{
A. M. El Massry \\ Chemistry Department. Faculty of Science, Alexandria University, Alexandria 21321. Egypt.
}

\begin{abstract}
Cyclocondensation of 2-chloro-3-substituted quinoxalines 4 with semicarbazide or phenylacetylhydrazine gave the corresponding 1,2,4-triazolo[4,3-a]quinoxalines 5 and 6 . Reaction of 4 with sodium azide afforded tetrazolo[1,5-a]quinoxalines $\underline{7}$. Heating of 2-hydrazino-3-substituted quinoxalines 9 with diethyl oxalate or acetic anhydride gave the corresponding 3-substituted-1,2,4-triazolo[4,3- $a$ ]quinoxalines 12 and 13 respectively. The 2-pyrazolylquinoxaline derivatives 14 were also obtained when 9 was heated with acetylacetone. 3-Benzyl-4-oxo-11-substituted-1,2,4-triazino[4,3-a]quinoxalines 16 were obtained upon cyclization of hydrazones 15 . with phosphoryl chloride. The prepared compounds were evaluated for antibacterial and antifungal activity.
\end{abstract}

\section{Introduction}

It has been reported that 1,2,4-triazolo[4,3-a]quinoxaline were found to possess antiallergic (1), antiviral $(2,3)$, anxiolytic (4), inhibition of passive cutaneous anaphylaxis (5) and selective adenosine antagonist (6-11) activities. Tetrazolo[1,5-a]quinoxalines were also showed fungicidal (12) activities. In the course of our investigations towards the synthesis of different heterocyclic derivatives from $\alpha$-keto acids (13-15), we have carried out the preparation of the title compounds.

\section{Results and Discussion}

Heating of equimolar amounts of $o$-phenylenediamine 1 with pyruvic acid derivatives, namely: phenylpyruvic acid $\mathbf{2} \mathbf{a}$ or benzylpyruvic acid $\mathbf{2 b}$ gave the corresponding 3 -substituted quinoxalin-2-ones $\mathbf{3}$, which underwent chlorination with phosphoryl chloride to give the 2chloroquinoxaline derivatives 4 .

Heating of $\underline{\mathbf{4 a}}$ or $\mathbf{4 b}$ with semicarbazide hydrochloride in the presence of hydrochloric acid gave products showed $\mathrm{C}=\mathrm{N}, \mathrm{CON}$ and $\mathrm{NH}$ IR absorptions. The products were assigned the structure of 3-oxo-10-substituted-1,2,4-triazolo[4,3-a]quinoxalines 5a and $\mathbf{5 b}$. Reaction of $\mathbf{4 a}$ or 4b with phenylacetylhydrazine gave the 3-benzyl-10-substituted-1,2,4-triazolo[4,3-a] quinoxalines $\underline{6} \mathbf{a}$ and $\mathbf{6} \underline{\mathbf{b}}$ respectively, their MS showed the molecular ion peak at $\mathrm{m} / \mathrm{z} 350$ and 364 respectively.

Heating of $4 \mathbf{a}$ or $4 \mathbf{b}$. with sodium azide in the presence of DMF at $100^{\circ} \mathrm{C}$ gave 4 substituted tetrazolo[1,5-a]quinoxalines $\mathbf{7 a}$ and $\mathbf{7 b}$. The alternative acyclic 2-azidoquinoxaline structure 8 was excluded because of the absence of the characteristic azido group around 2200 $\mathrm{cm}^{-1}$ (16) Scheme (1).

Substitution of the chloro atom of $\underline{\mathbf{4}} \mathbf{a}$ or $\underline{\mathbf{4}} \mathbf{b}$ with hydrazine moiety resulted in the hydrazino derivatives $\underline{\mathbf{9 a}}$ and $\underline{\mathbf{9}} \mathbf{b}$.

Heating of $9 \mathbf{a}$ or $9 \mathbf{b}$ with diethyl oxalate gave a single product in each case which showed ester carbonyl and $\mathrm{C}=\mathrm{N}$ absorptions at $1720,1617 \mathrm{~cm}^{-1}$ and $1720,1615 \mathrm{~cm}^{-1}$ respectively. These spectral data together with the elemental analyses ruled out the probability 
of the hydrazide 10 or the 3,4-dioxo-1,2,4-triazino[4,3-a]quinoxaline structures $\underline{\mathbf{1 1}}$, and therefore the assigned structures 3-carboethoxy-10-substituted-1,2,4-triazolo[4,3-a]quinoxalines 12a and 12b. (Scheme 2). The mass spectra of $12 \underline{\mathbf{a}}$ and $\underline{\mathbf{1 2 b}}$ showed the $\mathrm{M}^{+\bullet}$ peak at $\mathrm{m} / \mathrm{z} 332$ and 346 respectively.<smiles>Nc1ccccc1N</smiles>

1<smiles>O=C(O)C(=O)c1ccccc1-c1ccccc1</smiles><smiles>Cc1ccc2nc(Cl)c(-c3ccccc3)nc2c1</smiles>

(4)

(iv)<smiles></smiles>

8
a) $n=1$
b) $n=2$
(i) $\mathrm{POCl}_{3}$.
(ii) $\mathrm{H}_{2} \mathrm{~N} \cdot \mathrm{NHCONH} \cdot \mathrm{HCl} / \mathrm{HCl}$
(iii) $\mathrm{PhCH}_{2} \mathrm{CONHNH}_{2}$ : (iv) $\mathrm{NaN}_{3} / \mathrm{DMF}$

\section{Scheme (1)}

The IR spectrum of each single product obtained from heating of $9 \mathbf{a}$ or $\mathbf{9 b}$ with excess acetic anhydride, showed only $\mathrm{C}=\mathrm{N}$ absorptions at 1613 and $1610 \mathrm{~cm}^{-1}$ respectively. ${ }^{1} \mathrm{H}$ NMR spectrum of each product revealed a singlet of three protons intensity at $\delta 3.10$ and 3.14 respectively, due to methyl group protons, therefore, the products were assigned the 3-methyl1,2,4-triazolo[4,3-a]quinoxaline derivatives $\underline{13} \mathbf{a}$ and $\underline{\mathbf{1 3}} \mathbf{b}$ respectively.

The reaction of $\underline{\mathbf{9}}$ or $\underline{\mathbf{9}} \mathbf{b}$ with excess acetylacetone afforded a single product in each case, which showed $\mathrm{C}=\mathrm{N}$ absorptions at 1606 and $1609 \mathrm{~cm}^{-1}$ respectively. ${ }^{1} \mathrm{H}$ NMR spectrum of each product revealed two singlets each of three protons intensity due to two methyl groups protons and a singlet of one proton intensity due to pyrazolyl $\mathrm{CH}$ proton. This, beside the elemental analyses and MS spectra excluded the possible alternative products 13 and the products were assigned, therefore, 2-(3,5-dimethylpyrazol-1-yl)-3-substituted quinoxaline structures $\underline{14 a}$ and $\underline{14 b}$.

Condensation of $9 \mathbf{a}$ or $\underline{9 b}$ with phenylpyruvic acid gave the corresponding hydrazones $15 \mathbf{a}$ and $15 \mathbf{b}$ respectively which showed IR absorptions characteristic of $\mathrm{NH}, \mathrm{COOH}$ and $\mathrm{C}=\mathrm{N}$. Dehydrative cyclization of those hydrozones by heating with phosphoryl chloride gave single 
praduct in each case, which revealed IR absorptions of $\mathrm{CON}$ and $\mathrm{C}=\mathrm{N}$. These data, together with the elemental analysis assigned the structure 3-benzyl-4-oxo-11-substituted-1.2,4triazine[4,3-a]quinoxalines $\underline{16 \mathbf{a}}$ and $\underline{16 \mathbf{b}}$.<smiles>Cc1cc(C)n(-c2nc3ccccc3nc2-c2ccccc2)n1</smiles>

14<smiles>CCOC(=O)C(=O)NNC1=Nc2ccccc2NC1/C(=C/c1ccccc1)c1ccccc1</smiles>

10<smiles>Cc1nnc2c([C+]c3ccccc3)nc3ccccc3n12</smiles>

13<smiles>O=c1[nH]nc2c(-c3ccccc3)nc3ccccc3n2c1=O</smiles>

11<smiles>CCOC(=O)c1nnc2c([C](c3ccccc3)c3ccccc3)nc3ccccc3n12</smiles>

12

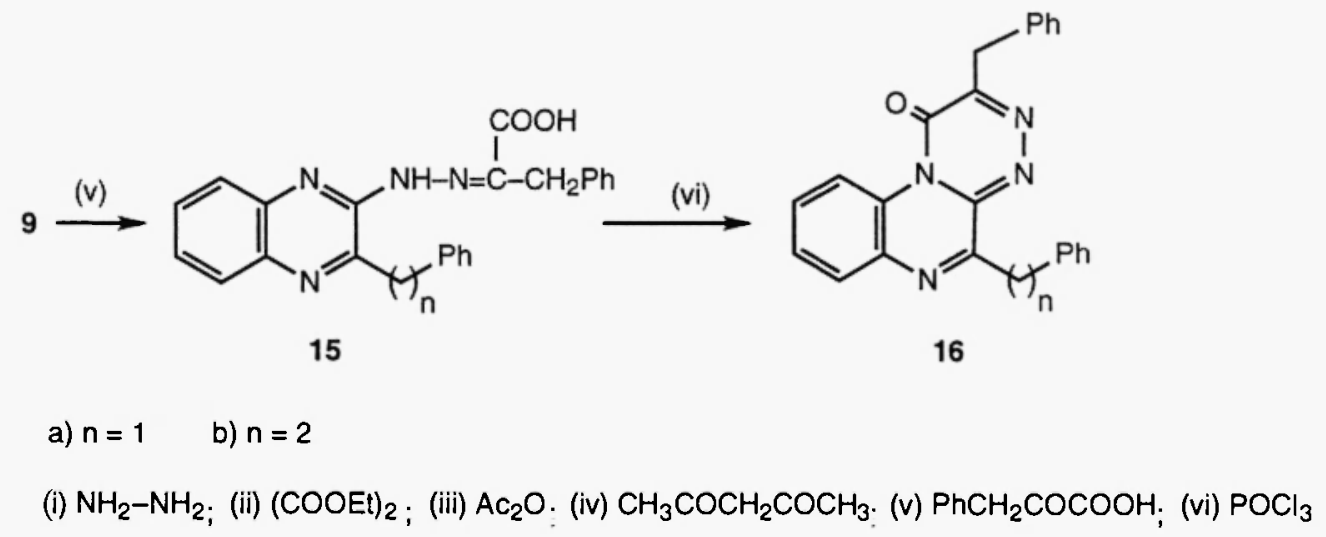

\section{Scheme 2}

Five test organisms representing different groups of microorganisms were used to evaluate the bioactivity of the tested compounds. Some of the prepared compounds were tested for their antibacterial activity against the Gram positive bacteria (Bacillus subtilis DSM 347b, Sarcina lutea" local strain", Staphylococcus aureus ATCC 25923), and the Gram negative bacterium (Escherichia coli ATCC 25922) as well as the antifungal activity against Candida albicans DMS 70443 using cup-diffusion technique (17) (Table I).

The effect of the tested compounds on the test organism was variable, compounds $\mathbf{5 b}$ and 14a were found to be inactive against the five test organisms used. Four compounds only were active only against only one test organism, three of which $(\mathbf{4 a}, 5 \mathbf{a}$ and $\underline{14 \mathbf{b}}$ ) were active against $S$. lutea, whereas $\mathbf{4 b}$ was active only against $S$. aureus. These four compounds are considered to be of specific or narrow range of antimicrobial activity. Compounds $\underline{9 b}$ and $\underline{\mathbf{1 5 b}}$ are of less specific activity, the first compound $\mathbf{9 b}$ inhibited growth of the three test organisms $S$. aureas, $E$. 
coli and $C$. albicans, and the second compound $\mathbf{1 5 b}$ inhibited growth of some of the Gram positive bacteria (B. Sublilis and $S$. lutea). Finally, two compounds (9a and 15a) exhibited a wide range of activity against the five test organisms .

Table (I) Results of Antimicrobial Activity

\begin{tabular}{|r|c|c|c|c|c|}
\hline \multirow{2}{*}{$\begin{array}{l}\text { Compd. } \\
\text { No. }\end{array}$} & B. Subtilis & S. lutea & S. aureus & E. coli & C.albicans \\
\cline { 2 - 6 } & & 17 & - & - & - \\
$\mathbf{4 a}$ & - & - & 10 & - & - \\
$\mathbf{5 a}$ & - & 16 & - & - & - \\
$\mathbf{5 b}$ & - & - & - & - & - \\
$\mathbf{9 a}$ & - & 23 & 14 & 18 & 21 \\
$\mathbf{9 b}$ & - & - & 12 & 10 & 12 \\
$\mathbf{1 4 a}$ & - & - & - & - & - \\
$\mathbf{1 4 b}$ & - & 12 & - & - & - \\
$\mathbf{1 5 a}$ & 15 & 17 & 12 & 14 & 14 \\
$\mathbf{1 5 b}$ & 12 & 13 & - & - & 14 \\
\hline
\end{tabular}

\section{Experimental}

Melting points were determined on Melt-Temp II melting point apparatus and are uncorrected. The IR spectra were recorded as $\mathrm{KBr}$ discs on a Perkin-Elmer-599 Spectrometer. ${ }^{\mathrm{I}} \mathrm{H}$ NMR spectra were obtained on a Brucher AC $250 \mathrm{MHz}$ Spectrometer using TMS as internal standard. MS were performed on a Hewlett-Packard 5995 gas chromotograph/mass spectrometer (at $70 \mathrm{eV}$ ). Microanalyses were carried out at the microanalytical unit, Faculty of Science, Cairo University; the experimental values were in good accordance with the calculated ones.

\section{3-Benzylquinoxalin-2-one $\underline{\mathbf{3 a}}$ :}

A solution of $1 \mathbf{a}(20 \mathrm{mmol})$ in ethanol $(10 \mathrm{ml})$ was treated with a solution of $\underline{\mathbf{2}}(20 \mathrm{mmol})$ in ethanol $(50 \mathrm{ml})$ and refluxed for $15 \mathrm{~min}$. The solid mass which separated out on cooling was crystallized from ethanol to give $\underline{\mathbf{3 a}}$ in $53 \%$ yield; M.p. $198-199^{\circ} \mathrm{C}$ Lit (18) $196^{\circ} \mathrm{C}$. IR: 1610 $(\mathrm{C}=\mathrm{N}), 1658 \mathrm{~cm}^{-1}(\mathrm{CON})$.

\section{3-(Phenylethyl)quinoxalin-2-one 3b :}

A solution of $1 \mathbf{b}(20 \mathrm{mmol})$ in ethanol $(10 \mathrm{ml})$ was acidified with acetic acid $(0.5 \mathrm{ml})$ and the mixture was treated with a solution of $2(20 \mathrm{mmol})$ in ethanol $(50 \mathrm{ml})$ and refluxed for $20 \mathrm{~min}$. It was then concentrated and the solid mass which spearated out on cooling was crystallized from ethanol to give $3 \mathrm{~b}$ in $51 \%$ yield; M.p. $207-209^{\circ} \mathrm{C}$. IR: $1607(\mathrm{C}=\mathrm{N}), 1659(\mathrm{CON}) \mathrm{cm}^{-1}$. MS $(\mathrm{m} / \mathrm{z}, \%): 250(100), 145(7), 117(2)$. ' $\mathrm{H} \mathrm{NMR}\left(\mathrm{CDCl}_{3}\right): \delta(\mathrm{ppm}) 3.07\left(\mathrm{~m}, 4 \mathrm{H}, \mathrm{CH}_{2}-\mathrm{CH}_{2}\right), 7.28-7.76$ (m, 9H, ArH), 12.37 (s, 1H, NH). 


\section{2-Chloro-3-benzylquinoxaline $\underline{4 a}$ :}

A mixture of $3 \mathrm{a}(10 \mathrm{mmol})$ and phosphoryl chloride $(30 \mathrm{ml})$ was refluxed for $2 \mathrm{~h}$. cooled and continuously poured into crushed ice. The mixture was neutralized with a saturated solution of sodium bicarbonate and the resulting precipitate was filtered olf, washed with water and crytallized from ethanol to give $4 \mathrm{a}$ in $87 \%$ yield. M.p. $84-85^{\circ} \mathrm{C}$; IR: $1605 \mathrm{~cm}^{-1}(\mathrm{C}=\mathrm{N})$. MS (m/.,\%): 256 (19), 254 (56), 219 (100), 91 (100). ${ }^{1} \mathrm{H}$ NMR (DMSO-d6): $\delta$ (ppm) 4.48(s, 2H. $\mathrm{CH}_{2}$ ). $7.32(\mathrm{~m}, 5 \mathrm{H}, \mathrm{ArH}), 7.86-8.14(\mathrm{~m}, 4 \mathrm{H}, \mathrm{ArH})$.

\section{2-Chloro-3-(2-phenylethyl)quinoxaline $4 \mathrm{~b}$ :}

Compound $4 \mathrm{~b}$ was prepared from $3 \mathrm{~b}$. $(10 \mathrm{mmol})$ and phosphoryl chloride $(30 \mathrm{ml})$ as described for the preparation of $\mathbf{4 a}$. It was crystallized from ethanol to give $\mathbf{4 b}$ in $85 \%$ yield. M.p. 56-58 ${ }^{\circ} \mathrm{C}$; IR: $1597 \mathrm{~cm}^{-1}(\mathrm{C}=\mathrm{N})$; MS (m/z,\%): 270 (13), $268(42), 233(44), 128(1), 91(100) .{ }^{1} \mathrm{H}$ NMR (DMSO-d 6 ) : $\delta$ (ppm) $3.14\left(\mathrm{~m}, 2 \mathrm{H}, \mathrm{CH}_{2}\right), 3.37\left(\mathrm{~m}, 2 \mathrm{H}, \mathrm{CH}_{2} \mathrm{Ph}\right), 7.20-7.32(\mathrm{~m}, 5 \mathrm{H}, \mathrm{ArH}), 7.85-$ $8.11(\mathrm{~m}, 4 \mathrm{H}, \mathrm{ArH})$.

\section{0-Benzyl-3-oxo-1,2,4-triazolo[4,3-a]quinoxaline 5a :}

A mixture of 4 a $(2.5 \mathrm{mmol})$ and semicarbazide hydrochloride $(2.5 \mathrm{mmol})$ in $75 \%$ ethanol $(30 \mathrm{ml})$ in presence of $12 \mathrm{~N}$ hydrochloric acid $(0.5 \mathrm{ml})$ was refluxed for $18 \mathrm{~h}$. The mixture was then concentrated and the solid product was filtered, washed with water, and crystallized from ethanol to give 5a in 51\% yield, M.p. 256-258\% (dec.). IR: $1607(\mathrm{C}=\mathrm{N}), 1701(\mathrm{CON})$ and 3140 $\mathrm{cm}^{-1}(\mathrm{NH}) .{ }^{1} \mathrm{H}$ NMR (DMSO-d 6$): \delta(\mathrm{ppm}) 4.26\left(\mathrm{~s}, 2 \mathrm{H}, \mathrm{CH}_{2}\right.$ ), 7.20-7.69 (m, 9H, ArH), 8.67 (s, $1 \mathrm{H}$, exchangeable $\mathrm{NH}$ ).

\section{3-Oxo-10-(2-phenylethyl)-1,2,4-triazolo[4,3-a]quinoxaline $\underline{5 b}$ :}

Compound $5 \mathrm{~b}$ was prepared from $4 \mathrm{~b}(2.5 \mathrm{mmol})$ and semicarbazide hydrochloride $(2.5$ $\mathrm{mmol})$ as decribed for the preparation of $\mathbf{5 a}$. It was crystallized from ethanol to give $\mathbf{5 b}$ in $55 \%$ yield, M. P. $215-217^{\circ} \mathrm{C}$ (dec.). IR: $1603(\mathrm{C}=\mathrm{N}), 1735(\mathrm{CON}), 3026 \mathrm{~cm}^{-1}(\mathrm{NH}) ; \mathrm{MS}(\mathrm{m} / \mathrm{z}, \%): 290$ (64), $246(24), 199$ (1), 91 (100).

\section{3,10-Dibenzyl-1,2,4-triazolo[4,3-a]quinoxaline 6a :}

A mixture of $\underline{4 a}(2.5 \mathrm{mmol})$ and phenylacetylhydrazine $(2.5 \mathrm{mmol})$ in $\mathrm{n}$-butanol $(10 \mathrm{ml})$ was refluxed for $8 \mathrm{~h}$. Evaporation of the solvent under reduced pressure gave a residue which was treated with water. The solid product was filtered, washed with water, and crystallized from ethanol to give 6a in $50 \%$ yield, M.p. $157-159^{\circ} \mathrm{C}$, IR: $1601 \mathrm{~cm}^{-1}(\mathrm{C}=\mathrm{N}) ; \mathrm{MS}(\mathrm{m} / \mathrm{z}, \%): 350(83)$, 349 (100), 259 (2), 231 (4), 91(32). IH NMR (DMSO-d 6 ): $\delta$ (ppm) 4.58, $4.94(2 \mathrm{~s}, 2 \mathrm{H}$ each, 2CH 2 ), $7.22-8.10(\mathrm{~m}, 14 \mathrm{H}, \mathrm{Ar}-\mathrm{H})$.

\section{3-Benzyl-10-(2-phenylethyl)-1,2,4-triazolo[4,3-a]quinoxaline $6 \mathrm{~b}$ :}

Compound $\underline{6}$ b was prepared from $\underline{4 b}(2.5 \mathrm{mmol})$ and phenylacetylhydrazine $(2.5 \mathrm{mmol})$ as described for the preparation of $\underline{\mathbf{6 a}}$. It was crystallized from ethanol to give $\underline{\mathbf{6 b}}$ in $60 \%$ yield, M.p. $155-157^{\circ} \mathrm{C}$. IR: $1611 \mathrm{~cm}^{-1}(\mathrm{C}=\mathrm{N})$ ) MS (m/z,\%): 364 (100), 273 (3), 245 (4), 140 (1). 


\section{4-Benzyltetrazolo[1,5-a]quinoxaline $\underline{7 \mathbf{a}}$ :}

A mixture of $4 \mathbf{a}(1.2 \mathrm{mmol})$ and sodium azide $(1.2 \mathrm{mmol})$ in dimethylforamide $(10 \mathrm{ml})$ was heated on a water bath for $3 \mathrm{~h}$. After cooling the mixture was pourd into cold water. and the solid which separated out was filtered, washed with water, and cystallized from ethanol to give $7 \mathbf{a}$ in $86 \%$ yield, M.p. $154-155^{\circ} \mathrm{C}$. IR: $1591 \mathrm{~cm}^{-1}(\mathrm{C}=\mathrm{N})$; MS ( $\left.\mathrm{m} / z, \%\right) ; 261(25), 232(100), 156(1)$, $91(88)$.

\section{4-(2-phenylethyl)-tetrazolo[1,5-a]quinoxaline $7 \mathrm{~b}$ :}

Compound $\underline{7 b}$ was prepared from $\underline{4 b}(1.2 \mathrm{mmol})$ and sodium azide $(1.2 \mathrm{mmol})$ as described for the preparation of 7a. It was crystallized from ethanol to give $\mathbf{7 b}$ in $92 \%$ yield, M.p. 110 $112^{\circ} \mathrm{C}$. IR: $1588 \mathrm{~cm}^{-1}(\mathrm{C}=\mathrm{N})$; MS (m/z,\%): 275 (25), $170(10), 142(1), 91(100) ;{ }^{1} \mathrm{H} \mathrm{NMR}\left(\mathrm{CDCl}_{3}\right)$ : $\delta(\mathrm{ppm}) 3.38\left(\mathrm{t}, 2 \mathrm{H}, \mathrm{CH}_{2}\right), 3.78\left(\mathrm{t}, 2 \mathrm{H}, \mathrm{CH}_{2} \mathrm{Ph}\right), 7.20-7.36(\mathrm{~m}, 5 \mathrm{H}, \mathrm{ArH}), 7.82-7.85(\mathrm{~m}, 2 \mathrm{H}, \mathrm{ArH})$, 8.22-8.26, 8.56-8.60 (2m, $1 \mathrm{H}$ each, $\mathrm{ArH})$.

\section{2-Hydrazino-3-benzylquinoxaline 9a :}

A solution of $4 \mathrm{a}(3.0 \mathrm{mmol})$ in ethanol $(24 \mathrm{ml})$ was refluxed with $90 \%$ hydrazine hydrate $(2 \mathrm{ml})$ for $2 \mathrm{~h}$. The mixture was concentrated, left to cool and the separated brown needles were filtered, washed with water then with ethanol, and dried to give $9 \mathbf{a}$ in $77 \%$ yield, M.p. 155$157^{\circ} \mathrm{C}$. IR: $1618(\mathrm{C}=\mathrm{N}), 3281 \mathrm{~cm}^{-1}(\mathrm{NH}) ;{ }^{1} \mathrm{H}$ NMR (DMSO-d 6$): \delta(\mathrm{ppm}) 4.25\left(\mathrm{~s}, 2 \mathrm{H}, \mathrm{CH}_{2}\right), 4.54$ $\left(\mathrm{s}, 2 \mathrm{H}, \mathrm{NH}_{2}\right), 7.19-7.80(\mathrm{~m}, 9 \mathrm{H}, \mathrm{ArH}), 8.56(\mathrm{~s}, 1 \mathrm{H}, \mathrm{NH})$.

\section{2-Hydrazino-3-(2-phenylethyl)quinoxaline 9b :}

Compound $9 \mathrm{~b}$ was prepared from $\underline{4 b} .(3.0 \mathrm{mmol})$ and $90 \%$ hydrazine hydrate $(2 \mathrm{ml})$ as described for the preparation of $\mathbf{9 a}$. It was crystallized from ethanol to give $9 \mathbf{b}$ in $71 \%$ yield, M.p. 146-148 ${ }^{\circ}$ IR: $1625(\mathrm{C}=\mathrm{N}), 3431 \mathrm{~cm}^{-1}(\mathrm{NH})$; ${ }^{1} \mathrm{H}$ NMR (DMSO-d 6$): \delta(\mathrm{ppm}) 3.11\left(\mathrm{~s}, 4 \mathrm{H}, \mathrm{CH}_{2}-\right.$ $\left.\mathrm{CH}_{2}\right), 4.53$ (bs, $\left.2 \mathrm{H}, \mathrm{NH}_{2}\right), 7.18-7.78(\mathrm{~m}, 9 \mathrm{H}, \mathrm{ArH}), 8.56(\mathrm{~s}, 1 \mathrm{H}, \mathrm{NH})$.

\section{0-Benzyl-3-carboethoxy-1,2,4-triazolo[4,3-a] quinoxaline 12a :}

A solution of 9a $(2.5 \mathrm{mmol})$ in diethyl oxalate $(10 \mathrm{ml})$ was refluxed for $1 \mathrm{~h}$, cooled and poured into crushed ice. The sticky product was washed with water several times and left overnight then filtered, and crystallized from ethanol to give $12 \mathrm{a}$ in $52 \%$ yield, M.p. $120-122^{\circ} \mathrm{C}$. IR: $1617(\mathrm{C}=\mathrm{N}), 1720 \mathrm{~cm}^{-1}$ (COOEt); MS(m/z,\%): 332 (100), 259 (32), 231 (6).

\section{3-Carboethoxy-10-(2-phenylethyl)-1,2,4-triazolo[4,3-a]quinoxaline 12b :}

The title compound was prepared from $9 \mathrm{~b} .(2.5 \mathrm{mmol})$ and diethyl oxalate $(10 \mathrm{ml})$ as described for the preparation of $\mathbf{1 2} \mathbf{a}$. It was crystallized from ethanol to give $12 \mathrm{~b}$ in $56 \%$ yield, M.p. $103-105^{\circ} \mathrm{C}$. IR: $1615(\mathrm{C}=\mathrm{N}), 1720 \mathrm{~cm}^{-1}$ (COOEt); $\mathrm{MS}(\mathrm{m} / \mathrm{z}, \%): 346(100), 273(9), 245$ (1) .

\section{0-Benzyl-3-methyl-1,2,4-triazolo[4,3-a]quinoxaline 13a :}

A solution of $9 \mathrm{a}(2.5 \mathrm{mmol})$ in acetic anhydride $(6 \mathrm{ml})$ was refluxed for $1 \mathrm{~h}$, cooled and poured into crushed ice. The resulting precipitate was filtered, washed with water, and crystallized from ethanol to give 13a in $92 \%$ yield, M.p. $176-178^{\circ} \mathrm{C}$. IR: $1613 \mathrm{~cm}^{-1}(\mathrm{C}=\mathrm{N})$; MS 
(m/z,\%): 274 (71), 273 (100), 232 (24), 91 (14). ${ }^{1} \mathrm{H} \mathrm{NMR}\left(\mathrm{CDCl}_{3}\right): \delta$ (ppm) $3.10\left(\mathrm{~s}, 3 \mathrm{H}, \mathrm{CH}_{3}\right), 4.63$ (s, 2H, $\left.\mathrm{CH}_{2}\right), 7.19-7.31(\mathrm{~m}, 5 \mathrm{H}, \mathrm{ArH}), 7.51-7.63,8.00-8.06(2 \mathrm{~m}, 2 \mathrm{H}$ each, $\mathrm{ArH})$.

\section{3-Methyl-10-(2-phenylethyl)-1,2,4-triazolo[4,3-a]quinoxaline $13 \underline{\mathrm{b}}$ :}

The title compound was prepared from $9 \mathrm{~b}(2.5 \mathrm{mmol})$ and acetic anhydride $(6 \mathrm{ml})$ as described for the preparation of 13a. It was crystallized from ethanol to give $\underline{13 b}$ in $92 \%$ yield. M.p. $145-147^{\circ} \mathrm{C}$. IR: $1610 \mathrm{~cm}^{-1}(\mathrm{C}=\mathrm{N})$; MS $(\mathrm{m} / z, \%): 288(100), 273(3), 183(15) ;{ }^{1} \mathrm{H}$ NMR $\left(\mathrm{CDCl}_{3}\right): \delta(\mathrm{ppm}) 3.14\left(\mathrm{~s}, 3 \mathrm{H}, \mathrm{CH}_{3}\right), 3.32,3.65\left(2 \mathrm{t}, 2 \mathrm{H}\right.$ each, $\left.2 \mathrm{CH}_{2}\right), 7.18-7.38(\mathrm{~m}, 5 \mathrm{H}, \mathrm{ArH}), 7.57-$ 7.61, 8.06-8.11 (2m, 2H each, $\mathrm{ArH})$.

\section{3-Benzyl-2-(3,5-dimethylpyrazol-1-yl)quinoxaline 14a :}

A solution of $9 \mathrm{a}$ ( $(2.5 \mathrm{mmol})$ in acetylacetone $(10 \mathrm{ml})$ was refluxed for $1 \mathrm{~h}$, cooled and poured into crushed ice to give an oily product, which solidified after a while. It was filtered, washed with water and crystallized from methanol to give $14 \mathrm{a}$ in $80 \%$ yield, M.p. $78-80^{\circ} \mathrm{C}$. IR: $1606 \mathrm{~cm}^{-1}(\mathrm{C}=\mathrm{N})$; MS (m/z,\%): 314 (100), 299 (19), $114(1),{ }^{1} \mathrm{H} \mathrm{NMR}\left(\mathrm{CDCl}_{3}\right): \delta$ (ppm) 1.83, 2.37 $\left(2 \mathrm{~s}, 3 \mathrm{H}\right.$ each, $\left.2 \mathrm{CH}_{3}\right), 4.60\left(\mathrm{~s}, 2 \mathrm{H}, \mathrm{CH}_{2} \mathrm{Ph}\right), 5.92(\mathrm{~s}, 1 \mathrm{H}$, pyrazolyl H), 6.86-7.12 (m, 5H, ArH), 7.74$7.80(\mathrm{~m}, 2 \mathrm{H}, \mathrm{ArH}), 8.00,8.18$ (2d, $1 \mathrm{H}$ each, $\mathrm{ArH})$.

\section{2-(3,5-Dimethylpyrazol-1-yl)-3-(2-phenylethyl)quinoxaline $14 \mathrm{~b}$ :}

The title compound was prepared from $9 \mathrm{~b} .(2.5 \mathrm{mmol})$ and acetylacetone $(10 \mathrm{ml})$ as described for the preparation of 14a. It was crystallized from ethanol to give $\underline{14 \mathbf{b}}$ in $80 \%$ yield, M.p. $109-111^{\circ} \mathrm{C}$. IR: $1606 \mathrm{~cm}^{-1}(\mathrm{C}=\mathrm{N})$; MS (m/z, \%): $328(100), 313(60), 223(5), 208(2), 128(4)$ : ${ }^{1} \mathrm{H} \mathrm{NMR}\left(\mathrm{CDCl}_{3}\right): \delta(\mathrm{ppm}) 2.26,2.35(2 \mathrm{~s}, 3 \mathrm{H}$ each, $2 \mathrm{CH} 3), 3.05,3.43\left(2 \mathrm{t}, 2 \mathrm{H}\right.$ each, $\left.2 \mathrm{CH}_{2}\right), 6.06$ (s, 1H, pyrazolyl H), 7.15-7.23 (m, 5H, ArH), 7.73-7.79 (m, 2H, ArH), 8.03, 8.13 (2d, 1H each, ArH).

\section{2-[3-Benzyl-2-quinoxalinylhydrazono]-3-phenylpropanoic acid 15a :}

A mixture of 9a $(1.5 \mathrm{mmol})$ and phenylpyruvic acid $(1.5 \mathrm{mmol})$ in ethanol $(25 \mathrm{ml})$ was refluxed for $30 \mathrm{~min}$. and left to cool. The resulting precipitate was filtered, washed with ethanol, and crystallized from ethanol to give 15a in $85 \%$ yield, M.p. $153-155^{\circ} \mathrm{C}$. IR: $1609(\mathrm{C}=\mathrm{N}), 1726$ (COOH), $3060 \mathrm{~cm}^{-1}(\mathrm{NH})$; MS ( $\left.\mathrm{m} / z, \%\right): 396$ (2), 350 (9), 219 (14), 91 (29), 45 (100). ' $\mathrm{H}$ NMR (DMSO-d 6 ): $\delta$ (ppm) 4.12, $4.27\left(2 \mathrm{~s}, 2 \mathrm{H}\right.$ each, $\left.2 \mathrm{CH}_{2}\right), 7.17-7.74(\mathrm{~m}, 14 \mathrm{H}, \mathrm{ArH}), 11.90(\mathrm{~s}, 1 \mathrm{H}, \mathrm{NH})$, $12.15(\mathrm{~s}, 1 \mathrm{H}, \mathrm{OH})$.

\section{2-[3-(2'-phenylethyl)-2-quinoxalinylhydrazono]-3-phenylpropanoic acid $15 \mathrm{~b}$ :}

The title compound was prepared from $9 \mathrm{~b}$ ( $1.5 \mathrm{mmol})$ and phenylpyruvic acid $(1.5 \mathrm{mmol})$ as described for the preparation of $15 \mathbf{a}$. It was crystallized from ethanol to give $\mathbf{1 5 b}$ in $86 \%$ yield, M.p. $147-149^{\circ} \mathrm{C}$. IR: $1606(\mathrm{C}=\mathrm{N}), 1740(\mathrm{COOH}), 3027 \mathrm{~cm}^{-1}(\mathrm{NH}) ; \mathrm{MS}(\mathrm{m} / \mathrm{z}, \%)$ : $392(8), 364(64)$, 233 (59), 128 (19), 91 (100).

\section{3,11-Dibenzyl-4-oxo-1,2,4-triazino[4,3-a]quinoxaline 16a :}


A solution of $\mathbf{1 5 \mathbf { a }}(1.2 \mathrm{mmol})$ in phosphoryl chloride $(10 \mathrm{ml})$ was refluxed for $2 \mathrm{~h}$, cooled and poured into crushed ice. The mixture was neutralized with a saturated solution of sodium bicarbonate and the resulting precipitate was filtered, washed with water, and crystallized from ethanol to give $16 \mathbf{a}$ in $43 \%$ yield, M.p. $170^{\circ} \mathrm{C}$. IR: $1600(\mathrm{C}=\mathrm{N}), 1695 \mathrm{~cm}^{-1}(\mathrm{CON})$; $\mathrm{MS}(\mathrm{m} / \approx, \%)$ : 378 (100), 349 (42), 232 (31), 91 (33); 'H NMR (DMSO-d 6 ): $\delta$ (ppm) 4.25, 4.55 (2s, $2 \mathrm{H}$ each. $\left.2 \mathrm{CH}_{2}\right), 7.20-7.43(\mathrm{~m}, 10 \mathrm{H}, \mathrm{ArH}), 7.69,7.91,9.48(3 \mathrm{~m}, 4 \mathrm{H}, \mathrm{ArH})$.

\section{3-Benzyl-4-oxo-11-(2-phenylethyl)-1,2,4-triazino[4,3-a]quinoxaline 16b:}

The title compound was prepared from $15 \mathrm{~b}(1.2 \mathrm{mmol})$ and phosphoryl chloride $(10 \mathrm{ml})$ as described for the preparation of $16 \mathbf{a}$. It was crystallized from ethanol to give $16 \mathbf{b}$ in $32 \%$ yield, M.p. $118-119^{\circ} \mathrm{C}$. IR: $1600(\mathrm{C}=\mathrm{N}), 1680 \mathrm{~cm}^{-1}(\mathrm{CON})$; MS (m/z,\%): 392 (92), 301 (43), 273 (12), 91 (100).

\section{Antimicrobial Screening}

The compounds were dissolved in propylene glycol at a concentration of $1 \mathrm{mg} / \mathrm{ml}$. The suitable medium (nutrient agar for bacteria and Sabouraud agar for fungi) was inoculated with the test organisms. A volume of the solution of each of the test compounds equivalent to $100 \mu \mathrm{g}$ was placed separately in cups ( $8 \mathrm{~mm}$ in diameter, $5 \mathrm{~mm}$ in height), cut in the agar. The plates were incubated at $37^{\circ} \mathrm{C}$ for $18-24 \mathrm{~h}$ for bacteria, and $48 \mathrm{~h}$ for yeast fungi (C. albicans), and the resulting inhibition zones were measured (Table 1). Propylene glycol, which exhibited no antimicrobial activity against the test organisms, was used as a negative control.

\section{Acknowledgement}

The auther is grateful to Prof. Dr. Y. M. Gohar, Division of Microbiology, Facutly of Science, Alexandria University for evaluating microbiological activities.

\section{References}

(1) B. Loev, J. H. Musser, R. E. Brown, H. Jones, R. Kahen, F. C. Huang, A. Khandwala, P. S. Goldman., M. J. Icibowitz, J. Med. Chem. 28, 363 (1985).

(2) S. W. Schneller, R. D. Thompson, J. G. Cory, R. A. Olsson, E. De Clereq, I. K. Kim, P. K. Chang, J. Med. Chem. 27, 924 (1984).

(3) S. W. Schneller, J. L. May, E. De Clereq, Croat. Chem. Acta 59, 307 (1986); Chem. Abst. 107. 7490 (1987).

(4) R. A. Hardy, J. R. A. Hardy, Jr, U. S. Pat. 4, 402, 958 (1983); Chem. Abst. 100, 6546 (1984).

(5) R. E. Brown, V. S. Georgiev, P. Kropp, B. Loev, Eur. Pat. 39, 920 (1981); Chem. Abst. 96, 69038 (1982).

(6) B. K. Trivedi, R. F. Bruns, J. Med. Chem $\underline{31}$, 1011 (1988). 
(7) R. Sarges, H. R. Howard, R. G. Browne, L. A. Lebel, P. A. Seymour, B. K. Koe, J. Med. Chem. 33, 2240 (1990).

(8) C. E. Müller. B. Stein, Curr. Pharm. Design 2, 501 (1996).

(9) C. E. Müller. Exp. Opin. Ther. Patents 7, 419 (1997).

(10) P. G. Baraldi, B. Cacciari, G. Spalluto, A. Borioni, M. Viziano, S. Dionisotti, E. Ongini. Current Med. Chem. 2, 707 (1995).

(11) B. Matuszczak, E. Pekala, C. E. Müller, Arch. Pharm. 331, 163 (1998).

(12) M. C. Shephard. S. R. Ramaswamy, Int. Congr. Plant Pathol. 3, 358 (1978).

(13) A. M. El Massry and A. Amer, Heterocycles 29 (10), 1907 (1989).

(14) N. Rashed, A. M. El Massry, E. S. H. El Ashry, A. Amer, H. Zimmer, J. Heterocycl. Chem. 27, 691 (1990).

(15) K. F. Atta, A. M. El Massry, H. A. Hamid, E. S. H. El Ashry and A. Amer, J. Heterocycl. Chem 31, 549 (1994).

(16) K. Makino, G. Sakata, K. Marimoto, Y. Ochiai, Heterocycles 28 (8), 2025 (1985).

(17) S. R. Jain, A. Kar, Planta Med. 20, 118 (1971).

(18) A. H. Cook and C. A. Perry, J. Chem. Soc. 394 (1943).

Received on August 19, 1999 
